\title{
La manda religiosa en santuarios de baile
}

\author{
Eduardo Valenzuela, Daniela Aranis \\ INSTITUTO DE SOCIOLOGÍA, PONTIFICIA UNIVERSIDAD CATÓLICA DE CHILE \\ CENTRO DE ESTUDIOS INTERCULTURALES E INDÍGENAS \\ evalenzc@uc.cl; dparanis@uc.cl
}

Resumen: Este estudio reflexiona sobre la naturaleza y cambios de la conciencia religiosa de bailarines y devotos que suben a las fiestas de La Tirana y de Andacollo; los dos santuarios de baile más importantes de Chile. Tomando como base datos de encuesta comparados se muestra un declive de la manda como motivo principal para bailar o visitar a la Virgen. Los bailarines tienden a sustituir la manda por una devoción libre que implica obligaciones de cumplimiento menos perentorias y con menos sanción exterior. La manda se orienta en una dirección favorable a la enseñanza clerical, aunque la devoción de santuario permanece en muchos aspectos fuera de una mediación sacerdotal y sacramental significativa. Los principales resultados del estudio provienen de una réplica de la encuesta que Juan van Kessel hiciera hace cerca de cincuenta años en la fiesta religiosa de La Tirana y que en esta oportunidad también se aplicó en el santuario de Andacollo.

Palabras claves: santuarios, fiestas religiosas, manda, devoción popular

Abstract: This study reflects on the nature and changes of the religious conscience of dancers and devotees on pilgrimage to the festivals of La Tirana and Andacollo, the two most important dance-sanctuaries in Chile. Based on comparative survey data, a decline of offering as the main reason for dancing or visiting the Virgin is shown. Dancers tend to substitute offerings for free devotion, which implies less strict committed obligations and less external punishment. The offering tends propitiously to clerical teaching, although the devotion remains in many respects independent from a significant clerical and sacramental mediation. The main results issue forth from a replica of Juan van Kessel's survey dated about fifty years ago La Tirana, which was this time also applied to the Andacollo sanctuary.

Keywords: sanctuaries, religious festivals, manda, popular devotion. 


\section{INTRODUCCIÓN}

La manda ha sido tradicionalmente el principal motivo por el cual los devotos se acercan a un santuario. El estudio de Van Kessel de 1970 mostraba que alrededor de dos tercios de los bailarines subían a La Tirana para cumplir con una manda. La manda era el núcleo de la piedad popular en La Tirana, y seguramente en todos los santuarios marianos, aunque no se dispone de una medición similar a la que hizo Van Kessel en ese entonces, salvo Huerta Pastén que encuentra un 36\% de manda en una muestra pequeña tomada en los alrededores del santuario de Andacollo en los años setenta ${ }^{1}$. La Tirana difiere de Andacollo en la importancia de la mediación sacerdotal que poseen las sociedades de baile. Aunque se bailaba en un templo, los grupos de baile del Norte Grande, en la época en que Van Kessel los estudió por primera vez se formaban desde una tradición exclusivamente familiar, sin contacto alguno con un sacerdote, al tiempo que los devotos permanecían largamente fuera de la mediación sacramental que ofrecía la Iglesia, con excepción del bautismo de niños que era entonces de rigor. El santuario mismo estaba localizado en un pueblo que despertaba sólo con ocasión de la fiesta y que carecía de soporte eclesiástico permanente. La Tirana -como otros santuarios de baile del Norte Grande de Chile- no han tenido un sistema de cofradías, es decir, de grupos de devotos organizados eclesiásticamente y cuya tarea era situar la devoción mariana dentro de la mediación sacramental, especialmente a través de novenas (misas diarias ofrecidas en los días previos de la celebración de la Virgen) y un horario muy ceñido de misas en los días festivos (que entre otras cosas obliga a suspender el estruendo de la música festiva). Los devotos presionan constantemente contra las sociedades de baile que, por el contario, desbordan continuamente la mediación sacramental, aunque suelen aceptarla y respetarla a regañadientes. El baile chino de Andacollo, por el contrario, fue siempre una tradición mucho más cercana y dócil a la jerarquía de la Iglesia y en el santuario mismo es posible encontrar las trazas de una mediación sacerdotal poderosa, especialmente desde que el santuario quedó en manos de misioneros claretianos hace un siglo. La Tirana de Van Kessel (como también los demás santuarios del Norte Grande, como Ayquina

1 E. HUERTA PASTÉN, La Religiosidad popular en el santuario mariano de Andacollo. (Tesis Licenciatura en Ciencias Religiosas. Facultad de Teología, Pontificia Universidad Católica de Chile, Santiago 1979). 
y Las Peñas) ofrecieron un caso especial de religiosidad popular, apenas mediada sacerdotalmente en los años setenta, lo que realza el interés de sus datos de encuesta.

\section{LA FIESTA DE LA TIRANA EN LA DÉCADA DE LOS SETENTA}

¿Cuáles son los principales resultados de la encuesta de Van Kessel de $1970 ?^{2}$ Ante todo, que la manda era el motivo principal por el cual se subía a la fiesta, sobre todo en el caso de los bailarines (ver Tabla). Los peregrinos que no formaban parte de una sociedad de baile también pagaban mandas, pero en una proporción menor. Bailar o peregrinar son actos más conmovedores de devoción que muestran la profundidad del compromiso y de la obligación respecto de la Virgen. En la época de los principales estudios de Van Kessel -los años setenta- era común que los bailarines objetaran la comodidad de los que podían subir a los santuarios en vehículos motorizados -buses, camionetas y autos- como sucede por doquier hoy en día. La inaccesibilidad de los santuarios y la falta de facilidades obligaban al esfuerzo de la peregrinación -lo que incluía al obispo subiendo a lomo de mula hacia la altura de Andacollosin contar con el hecho que los principales santuarios de devoción popular se encuentran generalmente alejados de las ciudades. La fatiga del baile religioso ha sido siempre una prueba de la autenticidad de la devoción. La accesibilidad de los santuarios también ha modificado la composición entre bailarines, peregrinos y devotos. Los cálculos de van Kessel indicaban que al menos la mitad de los fieles de La Tirana en los setentas eran bailarines, en lo que podía considerarse propiamente un santuario de baile puesto que los demás generalmente eran familiares y parientes que acompañaban al baile (se subía a La Tirana para bailar) algo que contrasta con la afluencia masiva de fieles no vinculados con

2 Algunos resultados de este estudio -que comprendía una encuesta, entrevistas y observación participante- están contenidos en el No 2, volumen XII, 1971 de Teología y Vida bajo el título "La Fiesta de la Tirana". Van Kessel mismo expone algunos resultados de su encuesta, JuAn van Kessel, Danseurs dans le Desert: une Étude de Dynamique Sociale (Editions Mouton, La Haye 1980). La encuesta fue realizada bajo condiciones y procedimientos imposibles de precisar hoy. Entre los papeles de Van Kessel sólo se logró recuperar el cuestionario y los resultados expuestos en tablas simples de frecuencia para cada pregunta del cuestionario. La muestra ( $\mathrm{n}=878$ casos) aparece dividida en cuatro grupos: bailarines (427), peregrinos (248), comerciantes (110) y turistas (93). 
grupos de baile que prevalece en la actualidad. Familiares y parientes que acompañaban al baile cumplían vicariamente una manda a través de aquel que peregrinaba o bailaba, por lo que la manda formaba parte del compromiso religioso de todos.

\section{LA MANDA HOY EN DÍA}

La reedición de la encuesta que Van Kessel hizo en La Tirana ${ }^{3}$-casi cincuenta años después-muestra un declive importante en el motivo de la manda para asistir al santuario en todas las categorías de asistentes que incluye también -y de manera especial- a los bailarines. La proporción de bailarines que actualmente declara que lo hace para cumplir una manda ha descendido desde $62 \%$ a $21 \%$, mientras que descensos similares se aprecian entre aquellos que suben solamente por devoción (ver Tabla). En Andacollo, todavía un tercio de los bailarines sube al santuario por manda, una proporción similar a la que ofrecía la encuesta de Huerta Pastén, aunque debe considerarse que este estudio no consideraba expresamente bailarines en su muestra. El declive de la manda queda especialmente -e incluso dramáticamente- documentado para el caso de La Tirana, a juzgar por la enorme reducción en las cifras de referencia. Como se apreciará más adelante, otras características específicas de la manda -sobre todo la exigencia de cumplimiento perentorio refrendada por una Virgen que castiga el incumplimiento- también varían en el mismo sentido de este declive.

¿En qué puede consistir entonces este desplazamiento desde la manda hacia la devoción simple como motivo para asistir a un santuario? La devoción libre puede retratarse de la manera como lo hace Rosa Navarro del baile de los Cuyacas de La Tirana: "Siempre me emociona verla, siempre le pido, uno siempre le está pidiendo cosas, más

3 El cuestionario de Van Kessel fue replicado en La Tirana por investigadores del Centro de Estudios Interdisciplinarios e Indígenas (CIIR) en 2016 bajo condiciones similares en tamaño y composición de la muestra. A fines de ese mismo año se aplicó una versión corregida del cuestionario en la fiesta de Andacollo. La muestra obtenida en La Tirana alcanzó a 1.004 casos, dividida esta vez en los cuatros grupos de Van Kessel, bailarines (454), devotos (260), comerciantes (127) y turistas (75) a los que se agregó un grupo personal religioso (88). En Andacollo se circunscribió la muestra $(\mathrm{n}=998)$ a bailarines (413), devotos (508) y personal religioso (77). 
que agradecer siempre le está pidiendo, (aunque) yo también bailo por agradecimiento, no porque tenga una manda o una promesa" 4 . En este caso, la petición y el agradecimiento no están situados en el contexto de una manda propiamente tal que implica casi siempre una promesa y un compromiso estricto de cumplimiento o de pago. La costumbre de bailar (o peregrinar) por manda estuvo muy extendida en todos los santuarios marianos. La manda es un compromiso siempre voluntario, aunque en la tradición de los bailes familiares, los niños eran consagrados a la Virgen y quedaban en cierta manera comprometidos de por vida en el marco de una promesa parental. Todavía hoy más de la mitad de los bailarines de La Tirana (53\%) y de Andacollo (56\%) declaran que fueron promesados por alguien de su familia, lo que sugiere que han bailado (o acompañado al baile) desde niños. El enrolamiento de niños ha sido documentado por Albás, por ejemplo, en el caso de un chino de Andacollo:

"Justo es entonces, Señora/Que en pago del beneficio/Lo consagre desde ahora/ A vuestro santo servicio. Recíbelo, Virgen pura/Como una ofrenda de amor/Que gustosos hoy hacemos/Agradeciendo un favor. Apenas cuenta dos años/Y será desde este día/Uno más de vuestros Chinos/Chinos de Santa Lucía”.

La transmisión hereditaria de la costumbre de bailar no requiere de algún acontecimiento específico de aflicción para constituir la manda, simplemente se baila por la salud y bienestar general de la familia y se cumple con la Virgen a través del esfuerzo y dedicación que se presta al baile. Entre bailarines hereditarios, el baile adopta muchas veces un carácter sacramental donde se coloca el conjunto de la vida bajo la protección de la Virgen a quien se le cumple escrupulosamente con respeto y veneración, tal como lo muestran las etnografías de Van Kessel para bailarines del Norte Grande, sin perjuicio de que también se soliciten gracias especiales de vez en cuando ${ }^{6}$. En estos casos la manda es objeto

4 L. Campos, R. Jiménez, J. Millar, V. Pavez, F. Ramírez y T. Téllez, Cuyacas. Música, Danza y Cultura en una Sociedad religiosa en la Fiesta de La Tirana (Fondo Nacional de las Cultura y de las Artes, Santiago de Chile 2009) 67.

5 P. Albas, Nuestra Señora del Rosario de Andacollo. Historia de la imagen y del santuario (Ediciones y Comunicaciones Claretianas, Santiago de Chile, 2000) 124.

6 J. van Kessel, Bailarines en el Desierto (Ediciones UC, Santiago de Chile 2018). 
de cumplimiento más que de pago. Este carácter sacramental del baile en áreas de baja mediación sacramental ha sido poco observado por la investigación teológica, aunque es evidente que en muchos casos el baile sustituye sin inconveniente los requerimientos sacramentales de la Iglesia, en el sentido de que se cumple entera y satisfactoriamente con la Virgen (y con Dios) a través del baile anual en el santuario de referencia. Esta forma de cumplimiento se comprueba también en la duración de la promesa: en La Tirana los bailarines llevan en promedio 16,3 años bailando, mientras que en Andacollo - con una muestra de mayor edad- se alcanza a 23,5 años, es decir, muchos son bailarines de larga data.

La forma más común de la manda, sin embargo, es aquella que se produce a través de episodios críticos entre quienes, por lo demás no han llevado una vida religiosamente calificada. Tampoco la manda común parece durar demasiado y se paga en un plazo razonablemente breve, y por esto mismo no existe evidencia de que sea un motivo principal de enganche en un grupo de baile de larga duración. La manda se hace generalmente por problemas de salud y bienestar. Laan contabiliza 18 de 22 declaraciones de manda relacionadas con la salud física, sobre todo dificultades con el embarazo y enfermedades con riesgo de sobrevida ${ }^{7}$, pero cada vez más se aprecian en los santuarios agradecimientos por haber conseguido títulos profesionales o universitarios. La manda consiste en solicitar expresamente un milagro, y por eso la mirada se tuerce inmediatamente hacia la imagen milagrosa de la Virgen o de algún santo benefactor. No existen indicios de que las peticiones por manda se hagan por motivos triviales, tal como las que reporta Graziano en el caso de los santos populares ${ }^{8}$ y que constituyen una de las objeciones eclesiásticas hacia la manda ${ }^{9}$. Más bien existen pruebas de lo contrario. Las mandas refieren a problemas difíciles de resolver o prácticamente imposibles (lo que constituye también una objeción sacerdotal) respecto de las cuales se ofrecen por ello mismo contraprestaciones proporcionales

7 E. LAAn, Bailarpara Sanar. Estudio de la praxis de la peregrinación de los bailes religiosos del norte de Chile (Centro de Investigación de la Realidad del Norte, Iquique, 1993).

8 F. Graziano, Cultures of Devotion: Fols Saints of Spanish America. (New York: Oxford University Press, 2007).

9 Para un análisis del punto de vista eclesiástico respecto de la manda véase JuAN Luis Isern, La Manda en la religiosidad Popular. (Colección Pastoral Litúrgica 2. Ediciones Paulinas, Santiago, 1974). 
y en ocasiones desmesuradas, que incluyen la peregrinación, pero también de mortificación de santuario (presentarse de rodillas ante la Virgen, por ejemplo). La manda permanece rigurosamente en el secreto y la intimidad de la relación entre el promesante y la Virgen, ni siquiera los familiares más próximos se enteran muchas veces de su contenido. La intimidad de la promesa contrasta con el cumplimiento que es público y notorio, no sólo se realiza a la vista de todos, sino que llama la atención, como sucede con todas las manifestaciones de la piedad de santuario. Tampoco la manda se revela una vez que se ha cumplido, sólo se hace público el testimonio de fe que queda inscrito en las prácticas, y en ocasiones en los exvotos que los fieles dejan grabados en las andas de la Virgen: "Gracias por el favor concedido"; que constituyen la señal inequívoca de una imagen milagrosa. Taylor señala que los santuarios mexicanos no llevan un "libro de milagros" como tampoco lo hacen los chilenos, a diferencia de los santuarios europeos que fueron siempre más pródigos en proclamar los milagros de la Virgen ${ }^{10}$. Esta parquedad de los exvotos puede explicarse por las objeciones eclesiásticas contra una difusión excesiva de la eficacia milagrosa de las imágenes religiosas. En la conciencia eclesiástica, los milagros deben asegurar una conversión, pero nada más, y constituyen por ende el recurso de los incrédulos antes del de aquellos que ya creen firmemente. Otra explicación también proporcionada por Taylor es que la imagen es de suyo milagrosa por su origen, de manera que no requiere pruebas adicionales de eficacia salvífica.

La manda requiere un cumplimiento perentorio y exacto, no es solamente un ruego o una solicitud, sino una promesa de reciprocidad que debe cumplirse escrupulosamente. La manda tiene la estructura del pago por el favor recibido, rara vez aparece como antesala del favor que se espera recibir. Además, muchos de los bailarines se comprometen por cierto número de años o de por vida incluso, de manera que están pagando una manda que puede haberse originado mucho tiempo atrás. La manda constituye un pago en el sentido convencional de la reciprocidad y, por consiguiente, conlleva el cumplimiento de una obligación. La obligación desaparece desde luego si la Virgen no cumple con su parte, pero rara vez se desvanece la fe en su capacidad milagrosa. Existen testimonios del

10 W. B. TAYLOR, Theater of a Thousand Wonders. A history of miraculous images and shrines in New Spain (Cambridge, Cambridge University Press 2016). 
vituperio de la Virgen cuando ésta no cumple, por ejemplo "Te vengaste muy cruelmente/ castigo sin compasión/ te llevaste a mi padre/que hoy está en el panteón/...Pero tú no lo escuchaste/a mi padre querido/ él te bailó treinta años/ y lo echaste al olvido"11, aunque la copla finaliza reiterando una devoción sincera que resiste cualquier decepción. En ocasiones puede haber desplazamiento entre una imagen y otra que pueda ser más cumplidora, pero estos desplazamientos están muy poco documentados, sobre todo para el caso de imágenes marianas. La fidelidad a la Virgen es un atributo esencial de la devoción, algo que debe mantenerse incluso cuando la Virgen no concede los dones solicitados.

Cuando la Virgen cumple, sin embargo, el pago debe ser estricto y obligatorio. Ante todo, predomina la creencia de que la manda debe ser cumplida al pie de la letra y no se puede modificar en ningún sentido relevante. Este carácter perentorio de la obligación (equivalente al literalismo bíblico de los evangélicos) también es objeto de reproche eclesiástico, tal como aparece formulado por el obispo Ysern, por ejemplo, para quien los devotos "no están obligados a cumplir la manda" e incluso puede existir conmutación y dispensa otorgadas por sacerdotes ${ }^{13}$, algo que rara vez ocurre desde luego. Este carácter literal del cumplimiento se ha desplomado desde $52 \%$ entre los bailarines de La Tirana hasta apenas $13 \%$ de aquellos consultados en el estudio más reciente (ver Tabla). La dispensa ("la manda puede no cumplirse" si existen razones justificables), sin embargo, tiene igualmente poco respaldo, salvo justamente entre personal religioso donde la opción de dispensa alcanza un $41 \%$, lo que indica hasta qué punto sobrevive todavía un contrapunto entre la conciencia clerical y la devoción popular de santuario.

La obligación de cumplir literalmente está relacionada con la conciencia de que la Virgen castiga el incumplimiento. El misionero claretiano de Andacollo, Principio Albás dice que "lo más singular es la

11 Citado de la recopilación de cantos de Juan Uribe Echevarría en R. ConTreras Mühlenbrock y D. González Hernández, Será hasta la vuelta del año. Bailes chinos, festividades y religiosidad popular del Norte Chico. (Consejo Nacional de la Cultura y las Artes, Santiago de Chile 2014) 322.

12 J. L. Ysern, La manda en la religiosidad popular (Ediciones Paulinas, Santiago de Chile 1974) 24.

13 J. L. YsERn, La manda... 
persuasión que han llegado a formarse los devotos de que la Virgen los castiga cuando no cumplen sus promesas en la forma que las hicieron o las difieren por largo tiempo sin motivo plausible"14. También "Dios deja sentir su mano justiciera con los que de algún modo faltan el respeto a su Santísima Madre"15. En el cuestionario de Van Kessel de 1970, la proporción que consideraba que la Virgen castiga se elevaba a 94\% en el caso de los bailarines y $71 \%$ en el de los devotos comunes y corrientes, es decir, se trataba de una convicción generalizada, algo que prácticamente ha desaparecido en La Tirana de hoy en día en que apenas un 16\% de los bailarines y 13\% de los devotos corrientes cree tal cosa. También en Andacollo, la proporción que cree que la Virgen castiga ofrece un registro muy bajo en consonancia con la devoción moderna que "invita a confiar en la misericordia de Dios que sobrepasa totalmente nuestras debilidades", según acota el comentarista del libro de Albás (escrito en la década de los cuarenta del siglo pasado) que, por el contrario, todavía celebraba el "temor reverencial a la justicia divina" que se encontraba entre los devotos de Andacollo ${ }^{16}$. Las dos grandes transformaciones de la manda -el sentido del cumplimiento literal y la creencia de que la Virgen castiga los incumplimientos- han marchado en la dirección que recomienda la teología sacerdotal de la manda.

Van Kessel distinguió aquello que la Virgen castigaba en dos clases de motivos: los motivos propiamente rituales o cúlticos, entre los que sobresale el incumplimiento de la manda, pero también faltarle el respeto o insultar a la Virgen y los motivos morales que consideraban las faltas corrientes relacionadas con el hurto ("robar"), el adulterio ("engañar al esposo/a") y la violencia conyugal ("golpear a la esposa"). Las proporciones que obtuvo Van Kessel en el caso de los bailarines oscilaban entre $75 \%$ para las faltas rituales y solamente $30 \%$ para las faltas morales, mostrando un evidente desequilibrio en el celo de la Virgen respecto de una u otra clase de falta (ver Tabla). Van Kessel llamó a este desequilibrio el ritualismo de los bailarines, por contraposición al moralismo que es más bien característico de una conciencia devota moldeada por el sentido sacerdotal del pecado. Las obligaciones respecto de la Virgen quedaban

\footnotetext{
14 P. Albás, Nuestra Señora..., 47.

15 P. Albás, Nuestra Señora..., 48.

16 P. Albás, Nuestra Señora..., 49-50.
} 
circunscritas al interior de la manda en el marco de una relación de reciprocidad estricta y, aparentemente por completo desconectadas de una devoción con consecuencias morales reconocibles en la vida diaria. A pesar de que las faltas seleccionadas por Van Kessel tenían un carácter idiosincrático y se encontraban en un umbral de tolerancia social mucho mayor que el que existe hoy (especialmente el adulterio masculino y la golpiza conyugal, "quien te quiere te aporrea"), no dejaban por ello de ser reconocidas como faltas susceptibles de alguna sanción o reproche eclesiástico y social. Para los bailarines, en cambio, tales faltas -y quizás cualquier otra más grave aún- no tenían calificación religiosa, es decir, no constituían faltas contra la Virgen (o contra Dios) que fueran susceptibles de expiación, corrección y enmienda religiosa, y por ello no alcanzaban el estatuto teológico de pecado. La manda religiosa quedaba ajena a cualquier implicación moral, lo que constituía (y todavía lo hace) el meollo del reproche sacerdotal contra la manda.

\section{LA MEDIACIÓN SACRAMENTAL}

Los datos de Van Kessel deben apreciarse en su alcance más general, es decir, en las dificultades que siempre tuvo la Iglesia para introducir la noción de pecado a través de la devoción eucarística. Quizás toda la diferencia entre la devoción de santuario y la devoción eucarística (sobre la que está construida la mediación sacramental) radica en el papel que cumple la penitencia, la confesión de los pecados como antesala de la comunión que desaparece en la fiesta religiosa. La devoción de santuario carece de un rito penitencial. Los bailes religiosos se presentan y se despiden de la Virgen dentro del templo en una actitud de homenaje, sin pronunciar ninguna palabra ni acto de expiación y sin hacer ningún propósito serio de enmienda y corrección. Es corriente interpretar los actos de mortificación festivos como actos penitenciales -especialmente el acto de arrastrarse y presentarse de rodillas ante la Virgen- pero no existe ninguna evidencia acerca de su carácter expiatorio. La mortificación festiva se entiende mejor como parte de la proporcionalidad de la manda: ante peticiones desmesuradas también el cumplimiento asume un carácter dramático y excesivo. En las etnografías de Van Kessel sobre los bailes religiosos del Norte Grande se presentan casos como el del Cojo del Baile de los Pieles Rojas de Alberto Madrid quien ofrece llevar su bote al santuario si logra pescar una albacora que le había resultado esquiva. Dice 
el Cojo: "Una manda, me la puedo: Si la Virgen me envía albacora sería el bote en adelante del todo de ella" ${ }^{17}$. También se cita más explícitamente el caso de Heriberto del mismo Baile quien, afligido por un parto de mal pronóstico de su esposa Gloria, le ofrece a la Virgen hacer la entrada al santuario de rodillas.

"Regresando otra vez al hospital, en compañía silenciosa de su virgencita en la cual tenía confianza, crecía en Heriberto la angustia y con la angustia creció su entrega ciega en la única que podía ayudarlo; la Virgen del Carmen. Entonces sus pensamientos se concretizaban más y más: «Ayúdala, Madre mía, y al niño también; y yo haré la manda de rodillas en la Tirana», dijo a su compañera invisible" ${ }^{\text {" }}$.

Una variante de la interpretación expiatoria de los actos de mortificación ritual se encuentra en Guerrero quien sostiene que "los ritos de sacrificio son una pena infringida sobre el cuerpo para purificarlo" 19 , y permitir su acceso a lo sagrado, una interpretación que colocaría a la manda (y al conjunto de la religión popular) en los marcos de una religión de la ascesis y de la pureza que, por el contrario, es típica de una religiosidad de virtuosos. La mortificación no es común entre los bailarines, sino algo excepcional (como lo es la urgencia y la desmesura de lo solicitado) y los bailes carecen por completo de un ritual de purificación en cualquiera de sus formas incluso más convencionales (lavarse los pies o echarse agua bendita, por ejemplo). El uso ostensible del cuerpo como medio de devoción y la evidente materialidad de la fiesta indican asimismo que en los bailes no existe una relación negativa con el cuerpo.

La mediación sacerdotal de la devoción religiosa generalmente va asociada con una intensificación de la conciencia del pecado de la que los bailes generalmente carecen. La insistencia de la pastoral de santuarios en la Misa frecuente es una indicación de esta mediación, tanto como la reticencia de los bailes religiosos ante un calendario muy ceñido de Misas. La devoción sacerdotal de santuario se consolida, sin embargo, a través de la formación de cofradías religiosas que se especializan en las novenas

17 J. van Kessel, Bailarines en el Desierto..., 329.

18 J. vAN KESSEL, Bailarines en el Desierto..., 302-303.

19 B. Guerrero, La Tirana: Chilenización y religiosidad popular en el Norte Grande (Instituto de Estudios Andinos Isluga Universidad Arturo Prat, Iquique 2015). 
de la Virgen y en el rezo del Rosario, signo inequívoco de la centralidad que adquiere la mediación sacerdotal de la fiesta religiosa. Las cofradías están ampliamente documentadas por Ramírez y Albás para el santuario de Andacollo, por ejemplo, pero falta por completo en los santuarios de Norte Grande chileno que no han formado cofradías en paralelo con los grupos de baile. El emplazamiento del santuario en pueblos festivos ha dificultado en parte la estabilización de cofradías, pero es evidente que la mediación sacerdotal es mucho menor en los santuarios del extremo norte. El caso de Andacollo, en cambio, es muy diferente. Albás, el misionero claretiano de Andacollo, se disculpa en su libro de haber considerado los bailes antes que la cofradía, "no ha sido, ciertamente, porque los creamos de mayor importancia objetiva, sino atendiendo ya a su prioridad de tiempo en cerca de un siglo sobre la cofradía, ya a su mayor resonancia en la historia de Andacollo" ${ }^{20}$. La cofradía es responsable de la advocación de la Virgen de Andacollo como Virgen del Rosario y probablemente también del traslado de la fiesta desde octubre hasta la nochebuena de diciembre, bajo pretexto de organizar las celebraciones del Niño Dios de los mineros recién pagos. Albás indica asimismo que la cofradía se hizo cargo alguna vez del cuidado y alhajamiento de la imagen del Rosario, aunque los bailes retuvieron el derecho de portar la Virgen fuera del templo. La función de las cofradías era insertar la devoción en la estructura sacramental de la Iglesia. La cofradía del Rosario instituye la misa cantada con sermón el día de la Virgen, el novenario y las celebraciones de las festividades marianas del calendario eclesiástico (Rosario, Natividad, Asunción y Concepción). Las exigencias de otra cofradía andacollina llamada Esclavonía del Santísimo Sacramento son todavía más profundas:

"los esclavos deberán decir diariamente cinco veces el alabado, visitar con frecuencia al Señor en su Sagrario, acompañarlo los que viven cerca de la Iglesia cuando se lleva el viático a los enfermos... Deben así mismo recibir la Sagrada Eucaristía, los días de Corpus, Jueves Santo y Ascensión del Señor, y sería bien comulgaran también las pascuas de Navidad, Resurrección y Pentecostés y los Domingos primeros de renovación" 21 .

\footnotetext{
20 P. Albás, Nuestra Señora..., 163.

21 P. Albás, Nuestra Señora..., 203.
} 
La Esclavonía -como lo indica su advocación al Santísimo Sacramentodesvía expresamente la devoción mariana hacia las fiestas cristológicas, tal como recomienda la pastoral de santuario, aunque todavía en un contexto en que la comunión frecuente no era de rigor. Las cofradías aprovechaban las indulgencias concedidas para cófrades, esclavos y hermanos que comulgaran y se confesaran apropiadamente, y tomaron cuerpo como una manera de morir bajo el amparo de una asociación religiosamente calificada, lo que incluía asistencia religiosa (y en ocasiones material) en la enfermedad y la muerte: "revestir mayor solemnidad el Viático y entierro de los fieles, al enriquecerse con muchas indulgencias y sufragios y con el fruto de tantas misas"22. Esta piedad sacramental se encontraba en las antípodas del baile religioso, enteramente despojado de sentido penitencial y de toda preocupación soteriológica. Albás reproduce la admiración del cura Cabañas por la Esclavonía en estos términos. "QQué impresión tan agradable produce ver comulgar 200 y 300 personas cinco veces al año, en un pueblo que contará, sumándole las quebradas de los alrededores, a lo más 500 vecinos" ${ }^{\prime 2}$. Las cofradías intervienen la comunidad de santuario provocando una escisión entre los devotos y bailarines que se enfrentan soterradamente, muchas veces bajo la mirada arbitral, sin embargo, de los curas párrocos. Esta clase de escisión -descrita por Charles Taylor- se produjo por doquier en el catolicismo parroquial de los siglos XVIII y XIX europeos, y condujo a la expulsión de la religión popular hacia fuera de los templos lo que precipitó su progresiva e inexorable extinción ${ }^{24}$. La fuerza de las cofradías marianas de Andacollo no alcanzó para tanto. Además, los misioneros claretianos que regentaron el santuario en el último siglo actuaron con moderación y prudencia frente a los bailes, tal como se aprecia por lo demás en el propio libro de Albás, que representa el esfuerzo por mantener unidos los dos extremos de la devoción andacollina. Detrás de este enfrentamiento se encuentran diferencias estilísticas. La devoción sacramental aprovecha la tranquilidad y el silencio religioso del templo menor (también de la fiesta chica de octubre que es menos concurrida), el espíritu de recogimiento y de oración interior que se aconseja en la piedad sacramental, pero sobre la capacidad de escuchar el sermón (algo que es imposible con el estruendo del baile), así como la solemnidad de

22 P. AlBás, Nuestra Señora..., 207.

23 P. Albás, Nuestra Señora..., 207.

24 CH. TAYLOR, La Era Secular (GEDISA, Buenos Aires 2014) 
la liturgia religiosa. Los bailes, por el contrario, ofrecen el contrapunto de un comportamiento festivo más ruidoso y heterogéneo. Pero sobre todo las cofradías introducen una piedad sacramental centrada en el ciclo confesional del pecado, el perdón y la indulgencia y en la comunión eucarística, algo totalmente ajeno al talante religioso de los bailarines de santuario.

\section{EL SENTIDO PENITENCIAL}

En los libros de cantos y coplas de los grupos de baile (recopilados también por Van Kessel) se utiliza la palabra "perdón" con alguna frecuencia, pero la palabra "pecado" que designa la calificación religiosa de la falta no aparece casi nunca ${ }^{25}$. La ausencia de un rito penitencial en los bailes religiosos está contenida en el motivo principal de la Entrada al templo, por ejemplo, en el baile de los Pieles Rojas Águilas Blancas de Iquique:

"Cansados llegamos/buscando a María/por cerros y pampas/de noche y de día/Campos naturales/déjanos pasar/porque los Pieles Rojas/ vienen a adorar/ venimos contentos/con gran alegría / a adorar a la madre/en su dichoso día/Virgen del Carmelo/madre poderosa/ para tus Pieles Rojas/eres milagrosa/Contentos salimos/de nuestra partida/a ver a la Madre/ en su hermosa guarida/Estos son tus hijos /todos de Iquique/ a tu templo, madre/ya vamos llegando" (Segunda Entrada de Pieles Rojas Águilas Blancas). ${ }^{26}$

En la fórmula de Pieles Rojas de Peña Chica se agrega un sexto verso característico "Échanos, señora/vuestra bendición/para que alcancemos/ de vos el perdón" ${ }^{27}$. En el baile del Gitano Escudero se agrega todavía la estrofa "Danos el aliento/y tu bendición/para que alcancemos/de Dios el perdón" 28 . Los motivos característicos de la entrada indican que se ha buscado a María incansablemente por campo y montañas y los peregrinos llegan siempre desde lejos fatigados y agotados al punto que se rinden

25 J. van Kessel, El Desierto canta a María. Bailes chinos de los Santuarios Marianos del Norte Grande. (Ediciones Mundo, Santiago de Chile 1977). Todas las coplas que se citan a continuación están tomadas de esta recopilación.

26 J. van Kessel, El Desierto canta a María..., 115.

27 J. van KesSel, El Desierto canta a María..., 120.

28 J. van KesseL, El Desierto canta a María..., 124. 
a sus pies en señal de cansancio. En algunos cánticos se hace ver que la fatiga proviene no sólo de la distancia recorrida sino también el peso del pecado "Desde lejas tierras/venimos, Señora/cargando en mi cuerpo/mi alma pecadora" (por ejemplo, en Gitano O’Higgins, Segunda entrada ${ }^{29}$ ), aunque esta fórmula no se repite demasiado.

En las Entradas al templo los peregrinos utilizan también el motivo de rendirse a los pies de la Virgen en posición de rodillas e imploran el perdón según una fórmula usual en todos los cánticos: "A ti madre Guadalupe/venimos a saludarte/en tu presencia divina/nos postramos a tus plantas/ Madre mía Guadalupe/de rodillas a tus pies/aquí nos tenéis, Señora/ échanos tu bendición" (Tomo II, Adoración del baile Cosacos Promesantes $\left.{ }^{30}\right)$. La fórmula "Échanos, Señora/vuestra bendición/ para que alcancemos de vos el perdón/" (Tomo II, Llegada del baile Cuyacas $^{31}$ ) es muy frecuente en todos los rituales de entrada. Rara vez se utiliza una fórmula teológicamente correcta como en la primera Entrada de Gitanos de María "Danos el aliento/ y tu bendición/para que alcancemos/de Dios el perdón” (Primera Entrada, Tomo I ${ }^{32}$ ) puesto que María perdona directamente. El sentido teológico del perdón solicitado, sin embargo, se aclara inmediatamente en la Entrada al templo del baile Cosacos, "Contemplamos todos/su magnificencia/pidiendo perdón/de tan larga ausencia". Y luego agrega, "contempla mi ausencia/al pie de tu altar/seremos perdonados/en vuestra presencia"33. La falta cometida es simplemente una ausencia prolongada que se repara inmediatamente con una presencia bienhechora, como cuando un hijo se disculpa de no haber visitado con suficiente frecuencia a su madre.

El sentido penitencial de los bailes religiosos queda situado en el dinamismo de la presencia/ausencia que constituye el núcleo de la devoción de santuario con su triple dramatización de la bienvenida, de la procesión y de la despedida de la Virgen. El peregrino se rinde

\footnotetext{
29 J. van Kessel, El Desierto canta a María..., 127.

30 J. van Kessel, El Desierto canta a María..., 35.

31 J. van Kessel, El Desierto canta a María..., 84.

32 J. van Kessel, El Desierto canta a María..., 109.

33 J. van Kessel, El Desierto canta a María..., 31.
} 
a los pies de la Virgen después de una ausencia prolongada y de un viaje extenuante y recibe con entusiasmo los beneficios de su presencia maravillosa. Todos los cánticos de entrada tienen este mismo sentido. La poética de la presencia es siempre abundante, "Que bella está María/ con sus rayos diamantinos/alumbrando a todo el mundo/y a sus hijos peregrinos" (Baile Gitano de Constantino Guzmán ${ }^{34}$ ). María se identifica con el Lucero de la Mañana, con la Aurora de julio, con el Sol reluciente, con el "alba risueña y sombría/ sale alumbrar con tu luz/ que es el día de María/ y el consuelo de Jesús". El éxtasis festivo, por su parte, se alcanza con la salida en andas de la Virgen y en el momento exacto en que aparece ante la multitud en el pórtico del templo, lo que reproduce el dinamismo de la aparición mariana. Este momento dramático se consigue plenamente en los santuarios de baile como La Tirana y Andacollo, que tienen la costumbre de sacar a la Virgen en procesión, pero está mucho más atenuado en otros santuarios de mayor mediación sacerdotal. La Virgen, en efecto, aparece, no habla. Todo en ella se realiza en el modo de la presencia que replica también el modo de la benevolencia y del don, en un sentido que se conserva todavía en la sinonimia del hacerse presente que significa al mismo tiempo estar a la vista, cara-a-cara y hacer un obsequio, regalar algo. La co-presencialidad entre el devoto y la Virgen es el acto primordial de la devoción mariana, el único que está revestido de densidad propiamente teológica. La imagen cobra una vida inusitada, una realidad eminente que hace olvidar su carácter de significante, para convertirse en una presencia. La imagen no es signo que refiere a una realidad que la trasciende, sino que contiene ella misma la realidad que significa. La diferencia entre imagen y presencia se mantiene firme en la conciencia del devoto. La Virgen que portan todos los grupos de baile en su estandarte o a veces como Virgen de bulto es todavía imagen, igual que toda la imaginería religiosa que se comercia en los santuarios y que tiene por lo demás una amplia aceptación. Tales imágenes se distinguen netamente de la verdadera imagen milagrosa que la devoción convierte en una presencia bienhechora, en una fuente al mismo tiempo de luz y de bondad según se expresa reiteradamente en toda la poética devocional de santuario. Esta misma diferencia entre imagen y presencia se replica en la distinción entre fiesta y espectáculo. Cuando la Virgen aparece en el pórtico del Templo todas las miradas se tuercen hacia Ella, de la misma

34 J. van Kessel, El Desierto canta a María..., 72. 
manera que el bailarín le baile sólo a Ella, con indiferencia de la mirada del espectador. La diferencia crucial en el teatro entre actor y espectador se disuelve en la unanimidad festiva que se consigue de manera privilegiada cuando la Virgen aparece y resulta casi imposible desviar la mirada hacia algo que no sea Ella misma, de manera tal que el espectador desaparece. La devoción convierte la imagen en presencia, del mismo modo que transforma el espectáculo en fiesta propiamente tal. Esta importancia de la co-presencialidad queda refrendada en las ceremonias de despedida que, como ocurre en toda relación de proximidad, se experimenta como algo dramático. El tono característico de esta dramatización se recoge en versos como éstos: "Tus indios los Pieles Rojas/llorando ya se retiran/ volveremos para el año/si Tú nos prestas la vida" (Pieles Rojas Águilas Blancas ${ }^{35}$ ). "Ay, labios, cómo no pueden/expresar su despedida/ay, ojos, cómo no lloran/de la partida de hoy día" (Gitanos Jesús Nazareno ${ }^{36}$ ). A menudo se implora el perdón de quien se ausenta "De rodillas tus Gitanos/esperando tu perdón/en la puerta de tu templo/échanos tu bendición" ${ }^{37}$, así como se reitera la promesa de volver el año entrante.

En los cancioneros de Van Kessel aparece en tono discordante una copla llamada los 10 Mandamientos (por ejemplo, del baile de los Morenos Rusos, "Los diez mandamientos/procuren guardar/ eterno tormento/ para no llorar/Contempla alma mía/el juicio final/a quien darán cuenta/ los hijos de Adán" ${ }^{\prime 38}$. Esta copla está situada fuera del contexto ritual de entradas, saludos y despedidas, siempre al comienzo y completamente desconectada del sentido de los textos que le siguen. Se trata de una copla penitencial de indudable influencia eclesiástica que conecta el cumplimiento de la ley y de las prescripciones morales con el horizonte de salvación que debe, no obstante ser desestimada como parte del sentido más propio de la devoción mariana que circunscribe el cumplimiento de la manda a exigencias rituales y carece por completo de toda inquietud soteriológica. Los Diez Mandamientos fijan el momento exacto en que determinados comportamientos morales adquieren calificación religiosa y aparecen propiamente como pecados, es decir, como ofensas contra

\footnotetext{
35 J. van Kessel, El Desierto canta a María..., 118

36 J. van Kessel, El Desierto canta a María..., 223

37 J. van Kessel, El Desierto canta a María..., 223

38 J. van Kessel, El Desierto canta a María..., 177
} 
Dios mismo, algo que estaba contenido de la misma manera en el relato del paraíso perdido del Génesis. La conjunción entre religión y moral a través de la noción de pecado tuvo enormes consecuencias, en particular la eliminación de la magia que, no en vano sigue siendo una acusación velada contra la clase de devoción que albergan los bailes religiosos (Cruz, por ejemplo, que observa en los bailes una manipulación mágica de lo numinoso ${ }^{39}$ ). Algunas costumbres como las que reportaba Ramírez en Andacollo revelan una disyunción completa entre sanación y regeneración moral que son características de lo mágico: "Los pobres no se vuelven a sus hogares sin llevar o el resto de una vela de cera que haya servido para iluminar el trono de la Virgen o un poco de grasa. Particularmente en la grasa tienen los devotos una fe especial. La llevan para curar enfermedades" $"$. No tenemos indicación acerca del estado actual de esta costumbre que recibiría hoy -como entonces- un enorme reproche eclesiástico. Las religiones morales toleran mejor el milagro, aunque a regañadientes también como sucede en la exhortación sacerdotal de concebir el milagro como fuente de conversión de los incrédulos o de publicitar moderadamente la eficacia milagrosa de las imágenes (tal como hacía Jesús de Nazaret con sus propios milagros de curación). También el milagro divorcia las probabilidades de sanación de todo esfuerzo profundo de regeneración moral y lo sitúa en la superabundancia de la gracia que contienen las imágenes y en la exigencia de colocarse en su proximidad y ante su presencia bienhechora. Esta es la razón por la que religiones más intensamente morales -como las de cuño protestante- expurgan las imágenes, incluyendo las imágenes marianas, y desconfían de cualquier intervención milagrosa de Dios en el mundo.

Los versos de los Diez Mandamientos de Van Kessel ("los Diez Mandamientos / procuren guardar/ eterno tormento/para no llorar") contienen también la conexión, específicamente cristiana, entre cumplimiento moral y salvación extramundana que introduce la inquietud soteriológica que es característica de la conciencia devota, un mecanismo especialmente importante en las cofradías marianas que preparaban al

39 A. Cruz, La religiosidad Popular Chilena (Centro de Investigaciones Socioculturales, Santiago de Chile 1979).

40 J .R. RAmírez, La Virgen de Andacollo. Reseña bistórica de todo lo que se relaciona con la milagrosa imagen que se venera en aquel pueblo (Imprenta "El Correo del Sábado" 1873) 36. 
devoto ante la muerte como se ha visto antes. Esta inquietud introduce todo el mecanismo penitencial que se profundiza en el catolicismo moderno con la confesión frecuente (y ya no solamente póstuma o una vez al año como recomienda la reforma post-tridentina) y pormenorizada de los pecados (que incluye también los pecados de poca monta) y con los requerimientos muy estrictos de contrición (arrepentimiento sincero) y atrición (firme propósito de enmendar la conducta). La intensificación del sentido del pecado es un atributo de la modernidad religiosa que cumple un rol fundamental en la eliminación de la religión popular, a la vez como religión ancestral (los padres también son pecadores y no pueden ser santificados) y como religión mágica-, puesto que antepone la conciencia moral como requerimiento de salvación. Albás se da perfectamente cuenta, sin embargo, cómo el baile sustituye el mecanismo penitencial:

\begin{abstract}
"No puede dudarse que los danzantes y chinos de la Virgen están intimamente convencidos de que agradan a la misma con sus piadosos bailes y de que Ella los bendice con toda suerte de favores y prodigios, y así en sus apuros y necesidades, en lugar de prometer limosnas, rezos o penitencias, creen más grato a la Virgen servir por algunos años o por toda la vida en alguna comparsa" ${ }^{\prime 1}$.
\end{abstract}

Los devotos permanecen en la convicción de que la gracia de María es sobreabundante, "madre compasiva", "madre de bondad", suficiente para obtener cualquier gracia, incluyendo la salvación eterna, por la que no manifiestan por lo demás ninguna preocupación especial. La sobreabundancia de la gracia mariana tiene dos motivos principales: por un lado, se otorga inmoderadamente a quienes no han hecho incluso ningún mérito para obtenerla; y, por otro lado, se otorga sin esperar ninguna retribución ulterior. La gracia de María consiste en que obra prodigios y maravillas, hace posible lo imposible, y en este sentido también es gracia plena. La gracia mariana es parecida al principio del ex opere operato de la gracia sacramental (típicamente eucarística) que indica que el sacramento (como el baile) es portador de gracia independientemente del mérito moral de quien lo pronuncia o de quien lo recibe, es decir, tiene eficacia por sí mismo. La mediación de la gracia sacramental introduce, sin embargo, un mecanismo penitencial que queda completamente desplazado en la devoción de santuario.

41 P. Albás, Nuestra Señora..., 98. 
¿Cuánto de todo esto queda en pie después de varias décadas de transformación de la conciencia religiosa de los bailes? Los bailarines (al menos los de La Tirana) tienden a sustituir la manda por una devoción libre que implica obligaciones de cumplimiento menos perentorias y con menos sanción exterior. Las mandas no deben cumplirse siempre al pie de la letra y la benevolencia de María alcanza a quienes eventualmente las incumplen, sobre todo por algún motivo justificado. Es posible que el relajamiento de estas condiciones de cumplimiento promueva la conciencia de que se baila más por devoción que por manda. La manda se orienta en una dirección favorable a la enseñanza sacerdotal, lo que concuerda con algunas indicaciones que muestran una mayor mediación eclesial de la piedad de santuario, aunque en este aspecto faltan los datos comparados.

Los dos reproches más vehementes de la jerarquía eclesiástica contra los bailes fueron las controversias respecto de bailar dentro de los templos y la práctica de la mortificación ritual. En general, se ha querido preservar el templo para la devoción eucarística, como recuerda el caporal del Baile de los Pieles Rojas de Alberto Madrid: "Antes estuvo aquí un tal Padre Antonio, que no quería que bailáramos en la Iglesia, porque decía que tenía guardada allí la sagrada hostia. Pero en el templo de la Tirana podemos bailar siempre. Día y noche" ${ }^{42}$. En Andacollo se baila sin inconvenientes en el templo mayor donde se instala la imagen milagrosa durante la fiesta, mientras que en el templo menor se conserva el sagrario y se suceden las misas una tras otra en una solución que puede llamarse de conveniencia. Por otra parte, la Iglesia no ha tenido reparos con las mandas que se pagan en bailes o peregrinaje, aunque desaconseja totalmente la mortificación, al punto que se ha prohibido expresamente entre los bailarines y subsiste sólo entre devotos no afiliados ${ }^{43}$. Guerrero cita una declaración extrema del obispo de Iquique Enrique Troncoso (1990) contra la mortificación que invita derechamente a sustituir la manda por los sacramentos, "pueden mostrarse otras formas de mandas que no dañen la integridad física de las personas: sacramentos, acciones de caridad o compromiso

42 J. van KesSEL, Bailarines en el Desierto..., 328.

43 B. Guerrero, "Sacralidades en Conflicto: las Mandas en la Fiesta de La Tirana y el Discurso Oficialista de la Iglesia Católica”, en La Tirana: Chilenización y religiosidad popular en el Norte Grande (Instituto de Estudios Andinos Isluga Universidad Arturo Prat, Iquique 2015). 
con la comunidad cristiana en forma permanente", pero por lo general no se ha predicado abiertamente contra la manda ${ }^{44}$.

Los bailes siguen siendo organizados y trasmitidos a través de la familia, aunque en Andacollo, una parte considerable de los bailes tiene contacto con alguna parroquia. Con todo, los peregrinos suben a los santuarios casi siempre acompañados de familiares. En el caso de los grupos de baile, el promedio de familiares o parientes que baila juntos alcanza a 8,1 en La Tirana y 6,8 en Andacollo. La devoción sacramental entre los bailarines es bastante considerable hoy y es posible que haya mejorado con el tiempo, al menos si se acreditan los reportes de Van Kessel acerca de la vieja tradición de los bailarines del Norte Grande que no iban a misa. "Heriberto no va nunca a misa, porque no se siente en ambiente, no tiene ropa decente como la gente que siempre va, le miran como si preguntaran: «qué hace usted aquí». No sabe cómo portarse en la Iglesia y no se sabe los cantos ni los rezos. No entiende el lenguaje del cura" ${ }^{\prime 4}$. Esta fractura entre la piedad sacramental y festiva parece haberse reparado en alguna medida. Actualmente alrededor de un tercio de los bailarines de La Tirana y Andacollo declaran que asiste regularmente a la Iglesia -una cifra bastante mayor que el promedio para población católica- y alrededor de la mitad son devotos de oración diaria. Además, no existen evidencia que el baile o la manda sustituyen la piedad sacramental como sucedía antaño según Albás. Aquellos que bailan tanto en La Tirana como en Andacollo declaran incluso en mayor proporción que aquellos que no lo hacen que van a misa regularmente o que rezan frecuentemente. En el caso de bailarines de La Tirana y Andacollo, la asistencia regular a misa alcanza al $28 \%$ y $31 \%$, respectivamente, mientras que los devotos comunes esta cifra es solamente de 24\% y 19\% (ver Tabla). En el caso del hábito de rezar diariamente fuera del templo, la proporción de alrededor de $50 \%$ que lo hace, es parecida al promedio nacional católico y parecida entre bailarines y no bailarines. No tenemos indicaciones adicionales acerca de la profundidad de esta mediación sacramental. Entre los bailarines de antaño, no sólo existía la rivalidad entre la Hostia y el Baile que se disputaban el templo, y una cultura devota que ahuyentaba a los

\footnotetext{
44 Con todo, la mortificación ritual sigue siendo ampliamente aceptada como un medio válido para pagar una manda.

45 J. van Kessel, Bailarines en el Desierto..., 330.
} 
bailarines de la misa dominical, sino también el horror a la confesión tal como aparece en las etnografías de Van Kessel, en boca de Alfredo, por ejemplo, también del Baile de los Pieles Rojas de La Tirana:

"Creo en Dios y en la Virgen, pero francamente, yo no creo en los curas. Si me hablan de esas cosas les digo que yo tengo mi fe, y eso no más. Quien sabe, nos quiere confesar la próxima vez; pero hasta allí no más, compañero. Cuando yo cometo un error, me confieso con la Virgen, y le pido perdón" 46 .

No existe una declaración más clara acerca de la sustitución del sacramento penitencial por el Baile tal como lo advertía Albás. La declaración de Alfredo debe tomarse en el sentido antedicho, es decir, las faltas de cumplimiento ritual que son las que constituyen propiamente faltas religiosas se reparan dentro del Baile, al margen de toda mediación sacerdotal. Aquello que se confiesa ante el cura son las faltas de índole moral que rara vez adquieren, sin embargo, un estatuto religioso.

\section{CONCLUSIÓN}

El ritualismo de los bailes que advirtió Van Kessel se ha desvanecido, pero no ha sido sustituido por una moralización de la conciencia religiosa. La Virgen ha dejado de castigar las faltas rituales, pero sigue siendo completamente indiferente frente a las faltas morales, sobre todo en $\mathrm{La}$ Tirana, algo menos en Andacollo que constituye en general un santuario más apegado a la mediación sacramental de la Iglesia y la conciencia eclesiástica del pecado. Todo esto es característico de una piedad popular que no ha sido -ni tampoco lo es actualmente-modelada por el andamiaje penitencial de la confesión que fue el mecanismo esencial para vincular religión y moral.

\footnotetext{
46 J. van Kessel, Bailarines en el Desierto..., 325.
} 
Tabla. Principales indicadores relacionados con la Manda en La Tirana (1970, 2016) y Andacollo (2016). En porcentajes.

\begin{tabular}{|c|c|c|c|c|c|c|c|c|}
\hline & \multicolumn{2}{|c|}{ La Tirana 1970} & \multicolumn{3}{|c|}{$\begin{array}{l}\text { La Tirana } \\
2016\end{array}$} & \multicolumn{3}{|c|}{$\begin{array}{l}\text { Andacollo } \\
2016\end{array}$} \\
\hline & $\begin{array}{l}\text { Baila- } \\
\text { rines }\end{array}$ & $\begin{array}{l}\text { Devo- } \\
\text { tos }\end{array}$ & $\begin{array}{l}\text { Baila- } \\
\text { rines }\end{array}$ & $\begin{array}{c}\text { Devo- } \\
\text { tos }\end{array}$ & $\begin{array}{l}\text { Reli- } \\
\text { giosos }\end{array}$ & $\begin{array}{l}\text { Baila- } \\
\text { rine }\end{array}$ & $\begin{array}{l}\text { Devo- } \\
\text { tos }\end{array}$ & $\begin{array}{l}\text { Reli- } \\
\text { giosos }\end{array}$ \\
\hline \multicolumn{9}{|l|}{ Motivación } \\
\hline Para ver y conocer la fiesta & 0.9 & 8.1 & 1.8 & 11.2 & 2.3 & 1.0 & 11.2 & 1.3 \\
\hline Por devoción & 37.2 & 54.8 & 75.6 & 65.8 & 92.1 & 63.0 & 55.7 & 62.3 \\
\hline Para cumplir una manda & 61.7 & 36.3 & 20.9 & 18.9 & 1.1 & 35.6 & 30.9 & 20.8 \\
\hline Por negocio o trabajo & 0.2 & 0.4 & 0.9 & 2.3 & 4.6 & 0.0 & 0.4 & 15.6 \\
\hline NS/NR & 0.0 & 0.4 & 0.9 & 1.9 & 0.0 & 0.5 & 1.8 & 0.0 \\
\hline \multicolumn{9}{|l|}{ Castigo } \\
\hline $\begin{array}{c}\text { Cree que la Virgen castiga a } \\
\text { las personas }\end{array}$ & 93.5 & 70.6 & 16.3 & 12.7 & 3.4 & 27.1 & 23.4 & 11.7 \\
\hline $\begin{array}{c}\text { A aquellos que no cumplen } \\
\text { la manda }\end{array}$ & 74.5 & 58.9 & 12.6 & 8.9 & 1.1 & 31.7 & 29.1 & 9.1 \\
\hline $\begin{array}{l}\text { A aquellos que faltan el } \\
\text { respeto a la Virgen }\end{array}$ & 72.9 & 56.9 & 12.1 & 8.1 & 1.1 & -- & -- & -- \\
\hline $\begin{array}{c}\text { A aquellos que insultan a la } \\
\text { Virgen }\end{array}$ & 74.5 & 52.0 & 12.8 & 9.6 & 2.3 & -- & -- & -- \\
\hline A quienes roban & 43.8 & 33.9 & 11.5 & 7.7 & 2.3 & -- & -- & -- \\
\hline $\begin{array}{l}\text { A quienes golpean a sus } \\
\text { esposas }\end{array}$ & 29.1 & 27.4 & 11.0 & 9.6 & 2.3 & -- & -- & -- \\
\hline $\begin{array}{l}\text { A quienes engañan a sus } \\
\text { maridos }\end{array}$ & 33.8 & 30.2 & 8.4 & 6.9 & 1.1 & -- & -- & -- \\
\hline $\begin{array}{c}\text { A quienes roban, cometen } \\
\text { adulterio o golpean a sus } \\
\text { esposas }\end{array}$ & 35.6 & 30.5 & 10.3 & 8.1 & 1.9 & 30.8 & 38.4 & 11.7 \\
\hline \multicolumn{9}{|l|}{ Cumplimiento } \\
\hline $\begin{array}{c}\text { La manda debe cumplirse al } \\
\text { pie de la letra }\end{array}$ & 51.8 & 38.7 & 12.6 & 14.2 & 9.1 & 31.7 & 31.3 & 10.4 \\
\hline $\begin{array}{l}\text { Puede ser cambiada por una } \\
\text { menos costosa }\end{array}$ & 42.4 & 48.8 & 66.5 & 62.3 & 48.9 & 53.8 & 51.6 & 48.1 \\
\hline Puede no cumplirse & 4.0 & 8.5 & 18.7 & 19.2 & 40.9 & 11.1 & 11.2 & 39.0 \\
\hline NS/NR & 1.8 & 4.0 & 2.2 & 4.2 & 1.1 & 2.2 & 5.9 & 2.6 \\
\hline \multicolumn{9}{|l|}{ Piedad sacramental } \\
\hline Asiste a misa regularmente & -- & -- & 28.9 & 23.9 & -- & 30.5 & 18.7 & -- \\
\hline Reza diariamente & -- & -- & 46.4 & 45.8 & -- & 54.2 & 52.8 & -- \\
\hline Total $(\mathrm{N})$ & 427 & 248 & 454 & 260 & 88 & 413 & 508 & 77 \\
\hline
\end{tabular}




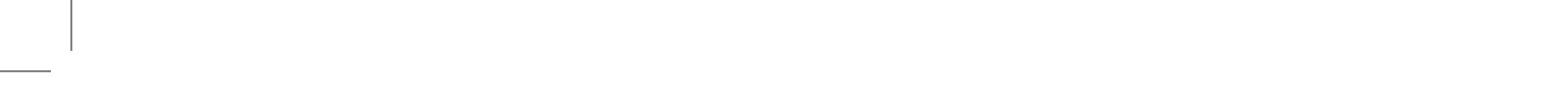

